and lost in the five o'clock hurry to get away. With a stomach content containing Perognathus and Meringis this owl either came with it from near the United States border or else pocket mice range farther north than hitherto known." Dr. Connell, of course, had then not been aware of the report which included Beaver Creek as within their range (in Nero, 1958).

What were believed to be pocket mouse burrows were observed at Red Fox $[=$ Redfox $\mid$ Lake (in 1937) and at Swift Current Creek south of Gull Lake (in 1946) as reported by J. Dewey Soper (1961). Redfox Lake is in the Strawberry Lakes district.

Recently I came across some earlier records of pocket mice which have apparently been overlooked and which do not appear, so far as I know, in the zoological literature. In a report in the American Journal of Botany, Alexander Bakerspigel (1956) reports having trapped 260 mammals during a survey of Saskatchewan rodents for certain fungi. This was "from May to September, 1955." Ten pocket mice are included in his list of specimens (but these are not available). Species and localities are not related in this report, although his several trapping localities are shown. In an effort to determine the site at which the pocket mice were trapped I wrote to Dr. Bakerspigel for further information. In a letter dated January 14, 1965, he states: "As far as I can determine the general areas where the 10 pocket mice were trapped were a few miles south of Saskatoon and around Watrous." The nearest trap- ping site to Watrous is shown in his published report (1956) as being fairly close to the Saskatchewan River. This leads me to suggest that these speciments were probably trapped within the sandy region on the east side of the Saskatchewan River and some distance west of Watrous. In any event these sites are pretty well within the known range as recently established by some definite records.

I should also like to report that a male pocket mouse taken west of Nokomis on September 17, 1959, died in captivity on August 5, 1963.

I wish to thank the following persons who rendered assistance in searching for pocket mice: Gary Anweiler, Ralph D. Carson, Robert R. Taylor, Charles Thacker, and Alan Wade. Mr. and Mrs. Adam Deutscher deserve thanks for introducing me to the Strawberry Lakes region. A campout with Mr, and Mrs. Doug Wade, in which my family participated, provided an excuse for looking for pocket mice in that interesting locality.

\section{LITERATURE CITED}

Anthony, H. E. 1928. Field book of North American mammals. G. P. Putnam's Sons, N.Y. 625 pp., 48 plates.

Bakerspigel, A.' 1956. Endogone in Saskatchewan and Manitoba. Amer. Journ. Bot., 43:471-475

Connell, R. 1962. Stomach contents of Great Horned Owls. Blue Jay, 20:56-58.

Nero, R. W. 1957. The pocket mouse in Saskatchewan. Blue Jay, 15:172-173.

1958. Additional pocket mouse records. Blue Jav, 16:176-179.

1959. Some recent mammals records. Blue Jay, 17:169.

1964. Sagebrush Vole range extension and other records. Blue Jay, 22:119-120.

Soper, J. D. 1961. Field data on the mammals of southern Saskatchewan. Can. Field-Nat., 75:23-40.

\title{
Fabric from an Early Saskatchewan Trading Post
}

\author{
by Alice B. Kehoe, Regina
}

A unique discovery was made by the Saskatchewan Museum of Natural History archaeological expedition excavating a trading post built on the Saskatchewan River near Nipawin. The post, occupied 1768-1774, was operated by François le Blanc, an experienced French voyageur, and James Finlay, Sr., a Scottish immigrant who had become a merchant in Montreal. Their venture was a pioneering one, the only earlier trading post in Saskatchewan having been the short-lived outpost of Fort Paskoyac run by the Chevalier à la Corne. The phenomenal success of François' and Finlay's post encouraged other independent traders to penetrate up the Saskatchewan River, and forced the Hudson's Bay Company to establish its first inland post at Cumberland House.

The Saskatchewan Museum excav- 


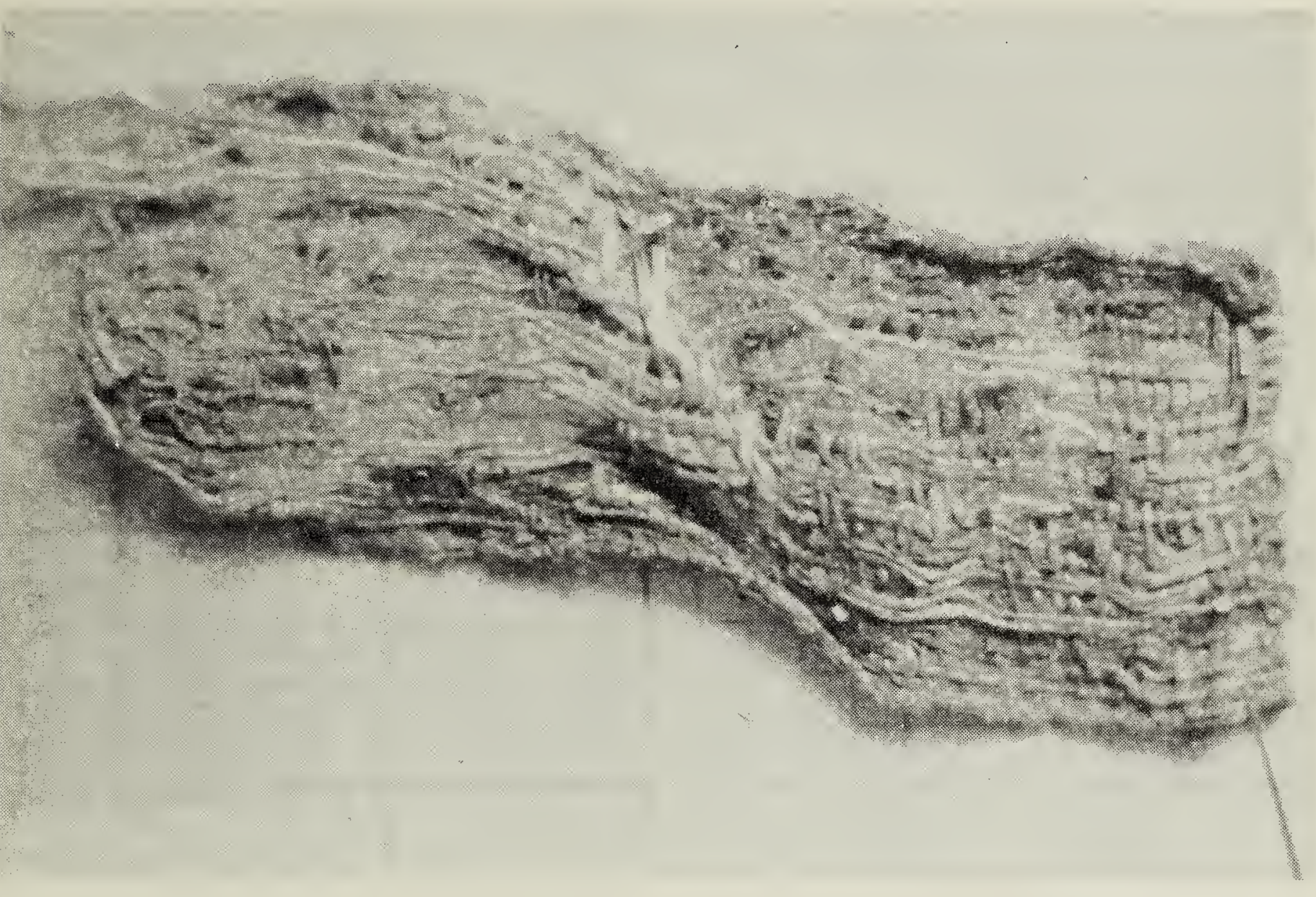

Photo by T. Kehoe

Fabric from site FhNa-19, the François-Finlay Trading Post (Scale: shown on $\mathrm{K} \& \mathrm{E} 5 \times 5 \stackrel{1}{=}$ " graph paper)

ated the site of the trading post during the summers of 1963 and 1964, under a grant provided by the Saskatchewan Power Corporation's program for archaeological salvage in the Tobin Reservoir area. The first season's work uncovered the well-preserved foundations of the set of buildings used during the last years of operation of the post. An exhibit on this compound, known as Francois' House, is on view in the Lower Gallery of the Saskatchewan Museum. The last season's work concentrated on another, less well-preserved set of buildings that probably represent the first cabins erected by the partners and their crew.

Although the Museum archaeologists found none of the fancy muskets and copper teapots allegedly recovered from the site by treasure-hunters, the Museum's painstaking excavation did produce a good sample of the gunflints, awls, glass beads, cheap trinkets, and other goods sold by the traders. Specimens of Indian-made pottery, scrapers (some made from broken gunflints), and a stone arrowpoint were also discovered, and will be of great value as examples of the artifacts made by Saskatchewan Indians around 1770, serving to date
Indian sites of this period in which similar specimens may be found. One of the most interesting artifacts, however, is a find that may never be duplicated: a strip of fabric preserved for

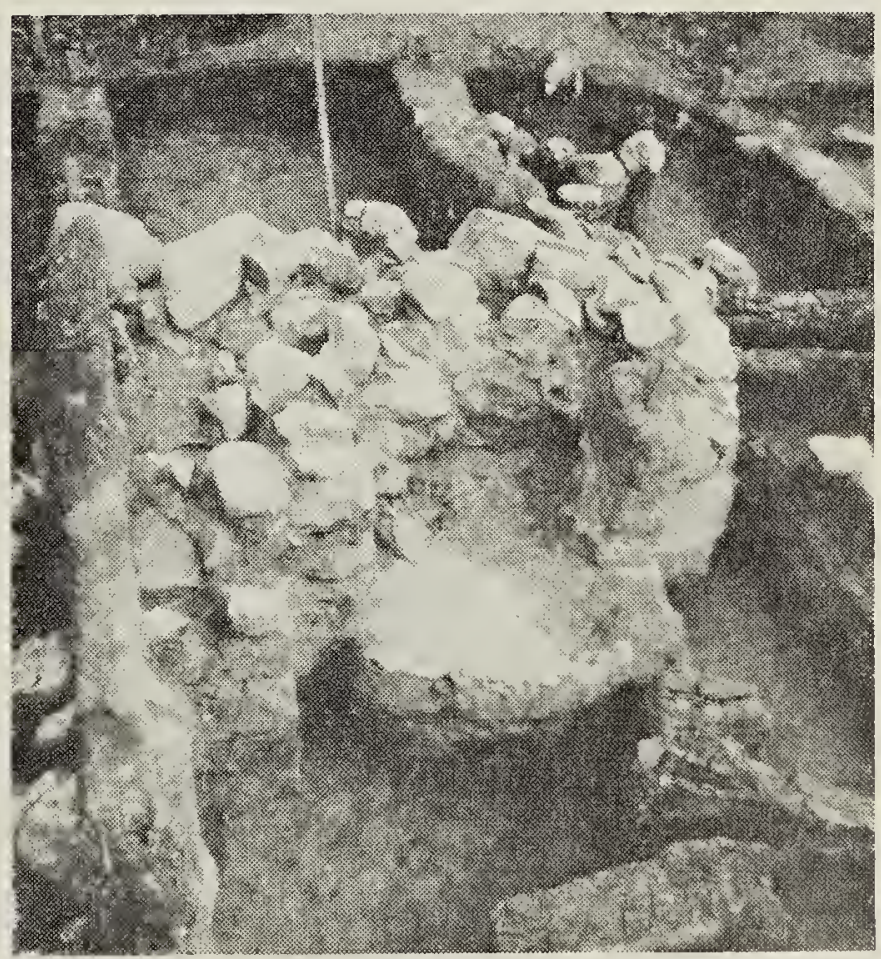

Photo by T. Kehoe

Stone fireplace and timbers from the François-Finlay site. The fabric was found in a small refuse pit a few feet from the fireplace. 
two hundred years because strips of copper had been interwoven with the threads. Copper salts formed as the fabric lay buried prevented the decay of the perishable cloth.

The fabric consists of a base of plain-woven flax thread, into which have been woven narrow, paper-thin strips of a copper alloyed with a small quantity of silver. The same metal (which may have been a deliberate alloy, or a poorly-refined copper) was used at the site for tinkling cones, rolled strips an inch or two long that were sewed or tied to clothing to make a pleasant tinkle in movement. It seems likely that the copper may have been brought to the post in sheets, to be cut up there and rolled into cones, rather than imported as finished cones. If this was the case, it is possible that the fabric was woven at the post, using copper cut into narrow strips instead of into rectangles for rolling. The flax may have been imported as thread, or perhaps unraveled from a linen shirt. (William Tomison, a Hudson's Bay Company man, reported that François wore a "ruffed Shirt," no doubt of linen.)

How was this copper-highlighted fabric used? It apparently was designed as a strip, not a piece of cloth. A broken prong, probably from a belt buckle, lay near the fabric, suggest. ing it may have served as a belt or an ornamental strap. Either the FrenchCanadian voyageurs or the Indians trading at the post might have worn such a strap. Either a Quebec demoiselle or an Indian maiden may have woven it for her man. Both belonged to peoples with long traditions of weaving, and although the French could produce finer fabrics than are known to have been made by the Indians of the eastern prairies and adjacent forests, the simplicity of the fabric found at François' and Finlay's post renders it within the skill of either. Thanks to the ingenious interweaving of copper, the strip of fabric has survived two hundred years to remind us of the gaiety that could enliven the harsh life at these remote trading posts.

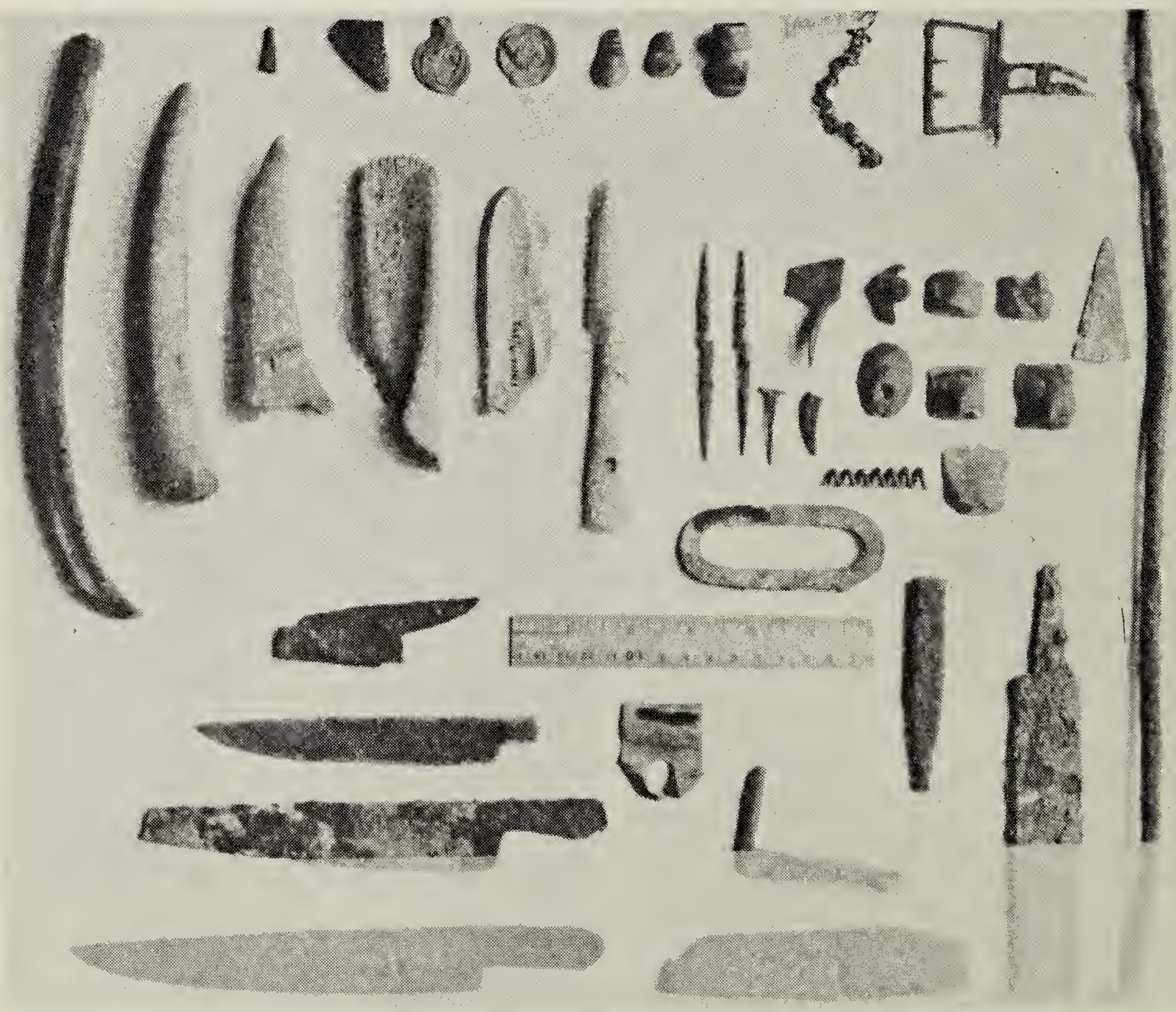

